\title{
Green R\&D for Eco-innovation and its Impact on Carbon Emissions and Firm Performance
}

\author{
Ki-Hoon Lee and Byung S. Min
}

\begin{abstract}
This paper examines the impact of green R\&D (research and development) investment for eco-innovation on environmental and financial performance. The research is based on the resource-based view and the natural resource-based view, which explicitly recognize the importance of resources and capabilities. Relying on a sample of Japanese manufacturing firms during the period of 2001-2010, the study focuses on green R\&D investment as a key proxy of eco-innovation and carbon emissions in environmental performance. Estimation results show that green $R \& D$ investments decrease carbon emissions and increase firm value, as measured by Tobin's Q. A further analysis suggests this negative effect of green R\&D is attenuated by an increase in non-green $\mathrm{R} \& \mathrm{D}$, particularly in energy-intensive industries.
\end{abstract}

Keywords: Green R\&D; eco-innovation; resource-based view; natural resource-based view; carbon emissions; firm performance 


\section{Introduction}

Global warming and its impacts on society in general leave little doubt that businesses play a major role in delivering environmental performance outcomes through production, operations, and efforts to achieve innovations of more sustainable products and practices (Lee, 2009; Lee and Kim, 2011). Increasing societal concerns over environmental degradation and the environmental externalities of business practices push corporate managers to reconsider their current business practices and look for ways to mitigate their firms’ environmental impact (Porter and Reinhardt, 2007). Some common examples include environmental management systems, pollution prevention, reuse and recycling, energy efficiency, and carbon management. However, the fundamental question now facing corporate managers is how these activities and strategies to reduce environmental impacts affect business performance (Porter and van der Linde, 1995; Lee and Min, 2014).

Over recent decades, debate has been ongoing as to the relationship between environmental innovation and business performance. While conventional wisdom holds that investing in environmental management increases costs without resulting in financial benefits (Palmer et al., 1995; Walley and Whitehead, 1994; Ambec and Lanoie, 2008), a new green perspective considers that early investments in environmental management offset operational costs and enhance financial returns in the long term (Porter and van der Linde, 1995; AragónCorrea et al., 2008; Sambasivan et al., 2013). In recent years, the management literature has increasingly emphasized the idea of "win-win" environmental strategies, through which proactive environmental management will benefit environmental and economic performance. In business practice, however, developing environmentally friendly products (i.e., green products) while remaining economically and commercially competitive is a significant challenge (Lee and Ball, 2003). Meeting this challenge to create win-win strategies requires more empirical evidence that is applicable to business performance.

In many cases, manufacturing firms attempt to develop green products or production supported by increased operational and energy efficiency (Dangelico and Pujari, 2010). Environmental innovation (or eco-innovation) is a common environmental strategy that many firms adopt to achieve superior environmental and economic performance simultaneously (Dangelico and Pujari, 2010; Triguero et al., 2013). Eco-innovation is

“the production, assimilation or exploitation of a product, production process, service or management or business methods that is novel to the organization (developing or 
adopting it) and which results, throughout its life cycle, in a reduction of environmental risk, pollution and other negative impacts of resources used (including energy use) compared to relevant alternatives (Kemp and Pearson, 2008, p. 7).”

Eco-innovations are strongly related to firms’ investment in research and development (R\&D). Importantly, the outcomes from eco-innovation are not immediately apparent, and firms need a long-term perspective on the innovation, particularly since "innovation cannot always completely offset the cost of compliance, especially in the short term before learning can reduce the cost of innovation based solutions” (Porter and van der Linde, 1995, p. 100). In general, the debate on the link between environmental (or eco-) innovation and firm performance has been inconclusive and lacking in consensus, indicating that the debate continues. More research on the impact of eco-innovation on firm performance is needed to provide a solid foundation that will encourage and guide corporate managers on how to achieve superior environmental and financial performance simultaneously.

In this research, carbon emissions serve as a proxy for environmental performance and green $R \& D$ as a proxy for eco-innovative $R \& D$ investment. The main objective of this study is to examine the relationship between green $R \& D$ investment and carbon emissions and the relationship between green R\&D investment and firm's financial performance.

The contributions of this study are three-fold. First, the study uses carbon emissions and green $\mathrm{R} \& \mathrm{D}$ data as proxies for environmental performance and eco-innovation at the firm level, with resulting unique datasets of Japanese manufacturing firms between 2001 and 2010. While the extensive use of industry-level proxies, such as patents, contributes to ambiguity in measurement (Ford et al., 2014), this practice has arisen mainly because of the limited availability of data at the firm level. However, industry-level data fail to reflect firms' strategic decisions on allocation of resources for the development of eco-technologies. In contrast to data in existing studies, the micro firm-level datasets in this study allow a more reliable examination of the relationship between green $R \& D$ and environmental and financial performance.

Second, this study's empirical results are expected to contribute to the existing controversial debate on the issues, especially as the link between R\&D investment and firm's environmental and financial performance has been controversial rather than conclusive (Etzion, 2007; Hart, 1995, 2005). Third, the case of Japan offers important insights into the research topic because most prior firm-level studies focus on U.S. (United States) industries. 
The ready generalization of learning outcomes from Japan about innovation and manufacturing over the decades testifies to the value of investigating how Japanese manufacturing companies face and manage environmental challenges-particularly carbon emissions - through green $R \& D$ and eco-innovation. As a scarcity of natural resources and land space require Japanese manufacturing firms to balance environmental and economic performance by achieving low-carbon emissions (Gutowski et al., 2005), the case of Japan offers important implications for carbon-constrained economies in Asia, Europe, and other regions.

The remainder of this paper is organized as follows. First, a review of the literature on eco-innovation and its impact on firm performance within the resource-based view and the natural resource-based view establishes a foundation for hypothesis development. Next, description of the data and model to test the hypothesis is followed by presentation of the results and further analysis and subsequent discussion on the effects on financial performance. The final section offers conclusions and implications of the study's findings.

\section{Theoretical Foundation and Hypothesis Development}

The resource-based view (RBV) and natural resource-based view (NRBV) provide an appropriate theoretical basis for discussing the contribution of resources and capabilities to the performance of eco-innovation. In particular, these theories shed light on the relationships among resources, capabilities, and performance, which constitute the basis for eco-innovation in a holistic view.

The RBV and NRBV essentially hold that the competitive advantage of a firm lies in heterogeneous resources that have the distinctive characteristics of being valuable, costly to imitate, and non-substitutable (Barney, 1991; Hart, 1995). Recognition that its resources by themselves are insufficient to create a competitive advantage raises the strategic importance of a firm's specific efforts or ability to exploit its resources to its own advantage. However, the RBV has been criticized as being unable to explain how to deploy resources to achieve a competitive advantage within a changing external environment (DeSarbo et al., 2005; Hart, 1995). In light of the currently changing institutional regulations, market pressure, and stakeholder influence related to the natural environment, the RBV has obvious limitations in explaining how to improve business performance relating to the natural environment. 
Furthermore, management theory, including the RBV, has ignored the constraints imposed by the natural environment, and "given the growing magnitude of ecological problems. . . this omission has rendered existing theory inadequate as a basis for identifying important emerging sources of competitive advantage” (Hart, 1995, p. 987).

With the increasing environmental pressures from the government and marketplace, firms face sustainability challenges to fostering effective eco-innovation capabilities (Dangelico and Pujari, 2010; Cheng et al., 2014). Building on the concept of the RBV, Hart (1995, 2005) developed the NRBV by including natural environmentally caused constraints and opportunities and arguing that a sustainable competitive advantage can be achieved through valuable, rare, costly-to-copy, and immovable firm resources and capabilities of the firm. According to the NRBV, to respond to the natural environment and achieve long-term success, firms need to accumulate resources and manage capabilities with a longer-term focus rather than a short-term focus on profits at the expense of the environment. An ability to envision sustainable technologies and products can lead to a firm's competitive advantage in the market. Further elaboration of the NRBV highlighted the links between environmental strategies, green capabilities, and competitiveness at a firm level (Hart, 2005; Hart and Dowell, 2011).

As a part of a sustainable development strategy, eco-innovation can be viewed as the cultivation of distinctive, long-term focused green capabilities, buttressed by top management support, eco technologies, and R\&D investment. External eco-innovation includes all green external activities of the firm, particularly those involving suppliers, government agencies, and market. Internal eco-innovation includes business practices for efficient and effective management of eco-innovation processes, particularly new product development (Cheng et al., 2014). While eco-innovation can be further defined in terms of products, processes, and organizations (Pujari et al., 2004; Lee and Kim, 2011, Triguero et al., 2013), this research adopts the definition of eco-innovation from Kemp and Pearson (2008), which highlights both the operational and organizational efforts of a firm to reduce negative environmental impacts. As a firm engages in eco-innovation and makes substantial efforts to reduce the negative effects of activities on the natural environment, many aspects of existing production, processes, and product development need to be reconsidered (Hart, 1995; Gonzalez-Benito and Gonzalez-Benito, 2005). 
As a result of adopting eco-innovation, a firm's environmental performance may improve. A study of environmental management and environmental performance described environmental performance at the firm level as a measurement of how successful a firm is in reducing its negative impact on the natural environment (Klassen and McLaughlin, 1996). Environmental performance includes efficient use of resources, reduction of wastes and energy consumption, and reduction of environmental risks (Aragón-Correa et al., 2008). To improve environmental performance using eco-innovation, firms need to invest in new environmental technologies to reduce pollution and carbon emissions. Eco-innovation can help to identify inefficiencies in production and existing environmental technologies, to improve energy efficiency and at the same time lead to product innovations (Melynk et al., 2003; Porter and van der Linde, 1995; Sambasivan et al., 2013).

In addition, investment in environmental technologies to reduce pollution and carbon emissions requires redesign of production, and product development is expected to improve the operational level of performance, such as by lowering energy consumption and carbon emissions. Some scholars have found a positive relationship between environmental investment and operational performance (Gonzalez-Benito and Gonzalez-Benito, 2005; Klassen and Whybark, 1999). For example, research has shown a positive link between R\&D expenditures and environmental management systems (Arora and Caso, 1996), but a negative link between R\&D expenditures and pollution emissions (Cole et al., 2005). In the same vein, research has also found a positive link between proactive environmental management and environmental performance (Lopez-Gamero et al., 2009). So far, the link between R\&D investment and environmental performance seems to be quite blurred (Etzion, 2007).

To adopt eco-innovation at a firm level, firms need to make a long-term commitment, mainly in the form of R\&D investment for new environmental technologies (Roome, 1994). R\&D activities on eco-innovation often center on the improvements of internal resources and capabilities to reduce environmental impacts. This study employs the term "green R\&D," which focuses on R\&D activities for eco-innovation. When firms adopt eco-innovation with green $R \& D$ investment and activities, they attempt to improve productivity and efficiency and to reduce costs and environmental impacts. However, firms usually underestimate the economic benefits from pollution reduction (Hart, 1995, 2005). This undervaluation can be driven by the costs associated with eco-innovation for sustainability, as firms can be unlikely to bear the full costs of eco-innovation, and thus can under-utilize green resources and capabilities. Incorporating eco-innovation into sustainable corporate strategy requires 
resolution of the conflicts between economic and environmental criteria by exploring new resource combinations and deploying existing resources for a sustainably better way (Hart, 1995; Sharma et al., 2007). Several studies have examined the relationship between environmental and firm performance (Griffin and Mahon, 1997; King and Lenox, 2001; Ambec and Lanoie, 2008; Elsayed and Paton, 2005; Horváthová, 2010). Notably, a metaanalysis of 64 empirical studies between 1978 and 2008 showed that 55\% of the studies found a positive, $15 \%$ a negative, and $30 \%$ an insignificant (or no) effect of environmental performance on economic performance (Horváthová, 2010). Despite an accumulation of empirical evidence over the last decade that eco-innovation and proactive environmental strategies are likely to produce positive impacts on financial performance, answers remain elusive.

In summary, therefore, green $R \& D$ investment for eco-innovation can help a firm develop unique resources and capabilities that can increase its eco-innovation and lead to superior environmental and financial performance. With a focus on green R\&D and carbon emissions, the following hypotheses are advanced:

Hypothesis 1. A firm's green $R \& D$ investment is positively related to carbon emissions (environmental performance).

Hypothesis 2. A firm's green $R \& D$ investment is positively related to financial performance.

\section{Data and Model}

Environmental performance data came from the Environmental Report Plaza, which is released by the Japanese Ministry of Economy, Trade and Industry. Financial data came from the Nikkei Economic Electronic Databank System (NEEDS). All variables used in the estimation are for Japanese manufacturing firms’ annual data between 2001 and 2010. Table 1 reports that the mean value of carbon emission (scaled by asset) is 2.09 with maximum value of 35.76. Carbon emission is only available variable to proxy environmental performance at firm level during our sample period. Environmental performance could be interpreted broadly from sustainability perspective. This may requires a large number of 
variables for pollutants as well as environmental capacity. Due to limited data availability we focus only on carbon emission to proxy environmental performance. One advantage of using carbon emission, however, is our research covers firm's environmental performance which is directly associated with the most impending global environmental issue. Carbon dioxide is reported the most important source of global warming. In addition, the hosting of the Kyoto Protocol in 1997 to decrease in carbon dioxide suggests that carbon emission has been one of the most important measures of environmental performance to Japanese government and firms.

Value of R\&D_total is calculated by summing the values of Green_R\&D and R\&D. Green_R\&D is firm's expenditure on R\&D particularly aiming at environmental purposes while $R \& D$ is expenditure on generic $R \& D$ without a specific for environmental purpose. Eco-innovation could be by either firm's deliberately targeted efforts or as secondary effect of other business activities. Availability of reliable data at firm level is the most important reason why we chose Green_R\&D to proxy for the environmental innovation. In order to minimise heterogeneity problem, all R\&D-related variables are scaled by sales values. Sales refer to total sales revenue which is regarded more associated with $R \& D$ than the size of firms based on firm's total asset. However, untabulated table indicates estimation using R\&D scaled by asset is consistent with our finding in this article. Our two key independent variables are Green_R\&D and R\&D. Mean values of Green_R\&D and R\&D are 0.88 and 8.17. However, mean values sometimes fail to describe data distribution when outliers exist. Inter-quartile value is obtained by the difference between the $25^{\text {th }}$ and $75^{\text {th }}$ percentiles. Interquartile is widely used to describe where a bulk of samples lies and the spread between the largest and smallest of the middle half of the data. The calculated inter-quartile values of the two variables are 0.59 and 5.34 respectively. This indicates that the bulk of both Green_R\&D and $R \& D$ values lie left hand side of the mean values due possibly to some firms' heavy 
expenditure on Green_R\&D and R\&D. We therefore estimated using log value of these variables as alternative but found similar results (not reported). Energy_Intensive is an indicator variable equal to 1 if a firm belongs to an energy-intensive industry and 0 otherwise. The energy-intensive sector includes the chemical, steel, metals, pulp and paper, and utilities industries. Mean value of Energy_Intensive implies around 57\% of sample belongs to an energy-intensive industry. We calculated Tobin's Q by (book value of asset + market value of equity)/book value of asset. Tobin Q is widely used to measure a firm value (Demsetz and Lehn, 1985) while firm’s accounting performance is subjected to changing accounting principles. Tobin Q is also a theory-based (but relatively easy to calculate) variable and it reflects market evaluation of firm performance (Hayashi, 1982). The reason why scaled by (book-value) asset. Asset is widely used as proxy of replacement costs of physical assets (Demsetz and Lehn, 1985). Mean value of the TobinQ is 1.3 which exceeds the unity, implying that average Japanese firm's profits are greater than the costs of asset. This suggests the affordability of Japanese firm's more investment and market evaluation of Japanese firms during our sample period is good.

\section{Table 1}

Summary statistics

\begin{tabular}{|c|c|c|c|c|c|c|c|c|}
\hline Variable & $\begin{array}{l}\text { Number of } \\
\text { firm-year } \\
\text { observation }\end{array}$ & $\begin{array}{l}\text { Mean } \\
\text { value }\end{array}$ & $\begin{array}{l}\text { Median } \\
\text { value }\end{array}$ & $\begin{array}{l}\text { Standard } \\
\text { deviation }\end{array}$ & $\begin{array}{l}75^{\text {th }} \\
\text { percentile }\end{array}$ & $\begin{array}{l}25^{\text {th }} \\
\text { percentile }\end{array}$ & $\begin{array}{l}\text { Minimum } \\
\text { value }\end{array}$ & $\begin{array}{l}\text { Maximum } \\
\text { value }\end{array}$ \\
\hline $\begin{array}{l}\mathrm{CO} 2 \text { (carbon } \\
\text { dioxide) }\end{array}$ & 2942 & 2.09 & 0.57 & 4.41 & 1.55 & 0.23 & 0.00 & 35.76 \\
\hline R\&D_total & 1562 & 7.63 & 4.38 & 17.51 & 7.58 & 1.61 & 0.03 & 369.40 \\
\hline Green_R\&D & 1842 & 0.88 & 0.20 & 5.33 & 0.64 & 0.05 & 0.00 & 190.92 \\
\hline R\&D & 944 & 8.17 & 4.22 & 20.20 & 7.12 & 1.77 & -8.75 & 360.01 \\
\hline Energy_Intensive & 3580 & 0.57 & 1.00 & 0.49 & 1.00 & 0.00 & 0.00 & 1.00 \\
\hline Capital intensity & 3453 & 1.89 & 1.27 & 3.68 & 1.66 & 0.98 & 0.23 & 56.86 \\
\hline Firm size & 3467 & 12.02 & 11.95 & 1.38 & 12.83 & 11.17 & 7.25 & 17.65 \\
\hline Leverage & 3446 & 50.05 & 50.05 & 20.06 & 66.47 & 36.02 & 1.67 & 125.89 \\
\hline Tobin’s Q & 3275 & 1.30 & 1.15 & 0.60 & 1.44 & 0.97 & -3.34 & 7.88 \\
\hline
\end{tabular}

Definitions and descriptions of variables: CO2 is calculated by CO2/ asset in percentage. R\&D_total, Green_R\&D and R\&D are calculated by Green_R\&D/sales and R\&D/sales. Energy_Intensive is an indicator 
equal to 1 if a firm belongs to an energy-intensive industry and 0 otherwise. Capital intensity is defined as asset/sales. Firm size is calculated by the natural logarithm of sales. Leverage is defined as debt/ (debt + equity). Tobin's Qis calculated by (book value of asset + market value of equity)/ book value of asset.

Table 2 reports the correlation matrix among variables. Correlation is pair-wise correlation which is calculated by covariance between the pair-wise variable scaled by standard deviations of the two variables. Carbon emissions (CO2) which is our outcome variable have negative correlations with R\&D_total and Tobin's Q but a positive association with Energy_Intensive, Capital Intensive, Firm Size and Leverage. The negative correlation between carbon emissions and $R \& D$ variables are as expected although the statistical significance is only for R\&D_total. Despite the statistical significance, the magnitude of correlation between carbon emission and R\&D_total seemed to be relatively small. However, this should not be concerned much because the pair-wise correlation shows only a picture of relationship between the two variables rather than the causal relationship. In particular, the calculated correlation will be confounded when there is a third variable affecting both the movements of the variables from its mean values simultaneously. As such we need to control for any possible third factors to clean the relationship between the two variables. Green_R\&D has a negative association with Energy_Intensive and Firm Size but a positive correlation with $R \& D$, Capital Intensive and Leverage. Like Green_R\&D, R\&D has negative association with Firm Size, but the negative association with Energy_Intensive is not statistically significant. As we described above for the correlation between CO2 and R\&D_total, however, this calculated pair-wise correlation could be confounded by a third factor. Thus, we will address this issue in detail using regression analysis. The benefit of regression analysis is the estimated coefficient shows a marginal effect of a variable on outcome variable, controlling for possible confounding variables. Green_R\&D has a positive association with $R \& D$, Capital Intensive, and Leverage whereas $R \& D$ has a positive correlation with Green_R\&D and Capital Intensive.

\section{Table 2}

Correlation matrix

\begin{tabular}{|c|c|c|c|c|c|c|c|c|}
\hline & $\mathrm{CO} 2$ & R\&D_total & Green_R\&D & $\mathrm{R} \& \mathrm{D}$ & $\begin{array}{c}\text { Energy } \\
\text { Intensive }\end{array}$ & $\begin{array}{c}\text { Capital } \\
\text { Intensive }\end{array}$ & Firm size & Leverage \\
\hline $\mathrm{CO} 2$ & 1 & & & & & & & \\
\hline R\&D_total & $-0.06 *$ & 1 & & & & & & \\
\hline Green_R\&D & -0.01 & $0.58 *$ & 1 & & & & & \\
\hline $\mathrm{R} \& \mathrm{D}$ & -0.04 & $0.99 *$ & $0.47^{*}$ & 1 & & & & \\
\hline Energy_Intensive & $0.30^{*}$ & $-0.07 *$ & $-0.07 *$ & -0.05 & 1 & & & \\
\hline Capital Intensive & $0.05 *$ & $0.66^{*}$ & $0.47^{*}$ & $0.68 *$ & $0.04^{*}$ & 1 & & \\
\hline
\end{tabular}




\begin{tabular}{lllllllll} 
Firm Size & $0.10^{*}$ & $-0.19^{*}$ & $-0.18^{*}$ & $-0.23^{*}$ & $-0.06^{*}$ & $-0.31^{*}$ & 1 & \\
Leverage & $0.26^{*}$ & $-0.06^{*}$ & $0.05^{*}$ & -0.05 & 0.02 & 0.01 & $0.23^{*}$ & 1 \\
Tobin Q & $-0.10^{*}$ & 0.04 & 0.01 & 0.03 & $-0.10^{*}$ & -0.02 & $0.13^{*}$ & $-0.16^{*}$ \\
\hline
\end{tabular}

*indicates significance at the $5 \%$ level. Our null hypothesis for a two-tailed test is absence of correlation between two variables. Statistical significance (not significance) at 5 percent level refers to a sample evidence which allows us to reject (cannot reject) the null hypothesis with the probability of type I error of 5 percent (i.e., $\alpha=0.05$ ).

\section{Estimation Model}

The restricted model is:

$Y_{i t}=$ cons $\tan t+\beta_{1}$ Green_ $R \& D_{i t}+\beta_{2} R \& D_{i t}+\beta_{3}$ Green_ $R \& D X R \& D_{i t}+\varepsilon_{i t}$

Where $Y_{i t}$ is outcome variable which is carbon emissions to investigate the hypothesis 1 and financial performance to examine the hypothesis 2. $i$ and $t$ respectively denote firm and year. Our main independent variable is Green_R\&D and the hypothesis 1 and 2 suggest the estimated coefficient of $\beta_{1}$ is positive. As we described above for Table 2, confounding effects through omitted variable may bias the estimated $\beta_{1}$. We therefore included two additional variables which are directly associated with the Green_R\&D variable. Green_R\&D X R\&D is an interaction variable generated by multiplication of Green_R\&D with $R \& D$. $R \& D$ variable captures firm's expenditure aimed at generic $R \& D$ such as to improve/creation of new technology rather than directly targeted at reducing environmental emissions.

Firm's environmental and financial performance can also be influenced by non-R\&D factors. To minimise estimation bias due to omitted variable, therefore, we included other control variable in the following unrestricted model.

The unrestricted model is:

$$
Y_{i t}=\text { cons tan } t+\beta_{1} \text { Green_ } R \& D_{i t}+\beta_{2} R \& D_{i t}+\beta_{3} \text { Green_ } R \& D X R \& D_{i t}+\text { Others }+\varepsilon_{i t}
$$

where Others are included observed control variables, such as firm size, leverage, capital intensiveness and a binary variable for energy intensiveness. To examine estimation bias due to unobserved omitted variables, an interaction variable and a year-industry variable are included. Year-industry variable 1xJT vector of binary variables, where $\mathrm{J}$ is 2-digit Japanese Standard Industry Classification and $\mathrm{T}$ is total number of years (i.e., 10). Year-industry effect 
is expected to capture the effect of time-varying at industry level on carbon emissions or financial performance. For example, industry effect, due possibly to different energy intensiveness in production, varies as the levels of yearly outputs change. The effects of exchange rate movement, as a macroeconomic shock, on firm usually differ depending on industry. Therefore, a year-industry variable is expected to control for the effect of industrylevel time-varying (macro) fixed effects in estimation of the firm performance model.

We estimated coefficients using the STATA (v.12) software which uses the minimum mean square linear predictor (least square linear predictor). Estimated coefficient is by: $\widehat{\beta}=\sum_{i=1} \sum_{t=1} \mathbf{x}_{i t}^{i} \mathbf{x}_{i t}$, where $\mathbf{x}$ refers to a vector of independent variables. The HuberWhite method for heteroskedasticity-robust standard error for the estimation coefficients is calculated by:

$$
\left.\hat{V}[\hat{\boldsymbol{\beta}}]=\sum_{i=1} \sum_{t=1} \mathbf{x}_{i t} \mathbf{x}_{i t} \widehat{\varepsilon}_{i t}^{2} / \sum_{i=1} \mathbf{x}_{i t}^{\prime} \mathbf{x}_{i t}\right]^{2} \text {, where } \hat{\boldsymbol{\varepsilon}}=Y_{i t}-\mathbf{x}_{i t}^{\prime} \hat{\boldsymbol{\beta}} \text { is the OLS residual. }
$$

\section{Estimation Results}

In Table 3, estimation results in Columns (1) and (2) report that both Green_R\&D and R\&D negatively affect carbon emissions but only Green_R\&D is statistically significant. The positive effect of Green_R\&D is consistent with Hypothesis 1. These results also imply that the inclusion or exclusion of industry-level fixed effects is without much difference in terms of magnitude of estimated coefficients. Effects in Columns (3) and (4) include interaction between Green_R\&D and R\&D. The results show that the positive effect of green $R \& D$ investment on environmental performance is attenuated by an increase in R\&D expenditure. This result implies that the estimated sign of this variable is negative and statistically significant. This finding also implies that the negative effects of Green_R\&D on carbon emissions are attenuated when a firm increases its $R \& D$ for non-environmental innovation. Intuitively, an increase in output resulting from non-green $R \& D$ can exacerbate environmental performance. To confirm this conjecture, another interaction variable is included by multiplying a binary variable for energy-intensive industry by this Green_R\&D X R\&D variable (Columns 5 and 6). 
Observation of the attenuated interaction effects between Green_R\&D and R\&D in Columns 3 and 4 led to examination for any difference between energy-intensive and other industries. Energy_Intenstive in Columns (5) and (6) are binary variables, indicating 1 when firms belong to an energy-intensive industry and 0 otherwise. As expected, the estimated coefficient of Energy_Intensive is positive and significant at the 1\% level. The positive sign of the doubled multiplication, Green_R\&D X R\&D X Energy_Intensive, suggests that the attenuating effect of Green_R\&D X $R \& D$ is intensified in energy-intensive industries compared to other industries. That is, an increase in outputs by non-Green R\&D in energyintensive industries naturally leads to poorer environmental performance.

\section{Table 3}

Effects of Green_R\&D and R\&D on Carbon Emissions

\begin{tabular}{|c|c|c|c|c|c|c|}
\hline & $(1)$ & $(2)$ & $(3)$ & $(4)$ & $(5)$ & $(6)$ \\
\hline \multirow[t]{2}{*}{ Green_R\&D } & $-0.061 * *$ & $-0.052 * *$ & $\overline{0} .176^{* * *}$ & $-0.314 * * *$ & $-0.116^{* *}$ & $-0.204 * * *$ \\
\hline & {$[0.016]$} & {$[0.032]$} & {$[0.000]$} & {$[0.000]$} & {$[0.010]$} & {$[0.000]$} \\
\hline \multirow[t]{2}{*}{$\mathrm{R} \& \mathrm{D}$} & -0.004 & -0.005 & $-0.018 *$ & $-0.041 * * *$ & $-0.023 * * *$ & $-0.034 * * *$ \\
\hline & {$[0.634]$} & {$[0.565]$} & {$[0.071]$} & [0.003] & {$[0.005]$} & {$[0.006]$} \\
\hline \multirow[t]{2}{*}{ Green_R\&DXR\&D } & & & $0.002 * * *$ & $0.003 * * *$ & $0.002 * * *$ & $0.003 * * *$ \\
\hline & & & {$[0.002]$} & {$[0.000]$} & {$[0.001]$} & {$[0.000]$} \\
\hline \multirow[t]{2}{*}{ Energy_Intensive } & & & & & $4.362 * * *$ & $3.850 * * *$ \\
\hline & & & & & {$[0.000]$} & {$[0.000]$} \\
\hline \multirow[t]{2}{*}{ Green_R\&DXR\&DXEnergy_Intensive } & & & & & $0.002 * * *$ & $0.002 * * *$ \\
\hline & & & & & {$[0.000]$} & {$[0.000]$} \\
\hline \multirow[t]{2}{*}{ Capital intensity } & & & & $0.206 * * *$ & & $0.140^{* * *}$ \\
\hline & & & & {$[0.000]$} & & {$[0.000]$} \\
\hline \multirow[t]{2}{*}{ Firm size } & & & & $0.513^{* * *}$ & & $0.443 * * *$ \\
\hline & & & & {$[0.000]$} & & {$[0.000]$} \\
\hline \multirow[t]{2}{*}{ Leverage } & & & & $0.046^{* * *}$ & & $0.034 * * *$ \\
\hline & & & & {$[0.000]$} & & {$[0.000]$} \\
\hline Year-industry effect & No & Yes & Yes & Yes & Yes & Yes \\
\hline \multirow[t]{2}{*}{ _cons } & $1.905^{* * *}$ & $2.385^{* * *}$ & $2.023 * * *$ & $-6.768 * * *$ & $-3.006 * * *$ & $-9.541 * * *$ \\
\hline & {$[0.000]$} & {$[0.000]$} & {$[0.000]$} & {$[0.000]$} & {$[0.000]$} & {$[0.000]$} \\
\hline $\mathrm{N}$ & 936 & 936 & 936 & 936 & 936 & 936 \\
\hline R2_a & 0.001 & 0.003 & 0.009 & 0.098 & 0.157 & 0.207 \\
\hline
\end{tabular}

Dependent variable is CO2 scaled by asset. Numbers in [ ] are Huber-White adjusted $p$-values. R\&D_total is sum of Green_R\&D and R\&D and all R\&D related data are mean-centered. Capital intensity is proxied by Asset scaled by sales. Firm size is proxied by sales in natural logarithm. Leverage is defined as Debt divided by (Debt plus Equity). Energy intensive is a binary variable. R2_a refers to adjusted R-square.

$*, * *, * * *$ refers to significance at the 10,5 , and $1 \%$ level respectively.

\section{Further Analyses}




\section{Economic Effect of R\&D and Green_R\&D on Carbon Emissions}

The result in Table 3 (Column 3) indicates that, when $R \& D$ takes its mean value of 8.18, the marginal effect of an increase in a one inter-quartile of Green_R\&D $(=0.59)$ on the ratio of carbon emission to asset is $-0.104 \%$. This is equivalent to approximately a $5 \%$ reduction of mean value of carbon emission (scaled by asset).

However, Graph 1 illustrates that this reduction effect of increase in one inter-quartile Green_R\&D is diminishing as a firm increases its R\&D expenditure. For example, the marginal effect of one inter-quartile Green_R\&D on carbon emission is -0.09 when $R \& D$ increases by a one inter-quartile range $(=5.348)$ from its mean value of 8.178 . This reduction is equivalent to $4.3 \%$ of mean value of carbon emission (scaled by asset).

--- Insert Graph 1 here ---

Looking at the impact of a one inter-quartile increase in $R \& D(=5.348)$ on the mean value of Green_R\&D (=0.889) is another way to characterize these economic effects.

As shown in Graph-2, considering that the R\&D and Green_R\&D variables are demeaned, a marginal effect of $\mathrm{CO} 2$ by an increase of one inter-quartile in $\mathrm{R} \& \mathrm{D}$ when firms take their mean value of Green_R\&D (=0.89) is affected solely by $R \& D$ because the interaction variable becomes annihilated. Thus, the marginal effect of an increase of one inter-quartile in $R \& D$ when Green_R\&D takes its mean value is -0.096 . This is the equivalent of $4.6 \%$ of mean value of carbon emissions (scaled by asset) and slightly smaller than that (=5\%) by an increase of one inter-quartile in Green_R\&D when R\&D takes its mean value.

However, this dynamic is attenuated as firms’ Green_R\&D increases. When a firm increases its Green_R\&D one inter-quartile range from its mean value $(1.49=0.89+0.59)$, the marginal effect on $\mathrm{CO} 2$ is -0.089 . This is equivalent to $4.25 \%$ of mean value of carbon emissions (scaled by asset).

In summary, results show that the marginal reduction effect of Green_R\&D on CO2 emission when firms take mean value of $R \& D$ is $5 \%$ and this is slightly greater than the marginal reduction effect of $R \& D$ when firms take the mean value of Green_R\&D. Results 
also show that the dynamic marginal reduction effect of Green_R\&D (R\&D) is diminishing as firms increase $R \& D\left(G r e e n \_R \& D\right)$ values.

\section{--- Insert Graph 2 here ---}

\section{Effects on Financial Performance}

Results in Column (1) in Table 4 report that estimated coefficients of both Green_R\&D and R\&D have a positive association with Tobin's Q. This finding illustrates that the positive effects of Green_R\&D on firm value is robust even when we control for firm's expenditure on generic (i.e., non-environmental) R\&D. Note that Green_R\&D, R\&D and its interaction variables are mean-centred ones. These mean-centred variables do not affect the estimated coefficients and standard errors but only the constant value. That is, the value of 1.528 on Column (1) implies the estimated population firm value (Tobin Q) is 1.528 when Green_R\&D (and R\&D and the interaction variable) has its mean value. In contrast, the interaction between these two variables, Green_R\&D x R\&D, has a negative sign, implying the attenuated positive effects of the two variables. For example, the positive effects of Green_R\&D on Tobin's Q is attenuated as firm increases its (generic) R\&D expenditure. This finding is almost symmetrical to the results of the benchmark estimation (Column 3) in Table 3 above. As expected, results in Column (2) report that carbon emission decreases the firm’s Tobin’s Q value.

These findings are robust irrespective of model specifications from Column (3) to Column (6), although the magnitude of estimated coefficients varied somewhat. Considering the measurement of Tobin's Q, book value of assets plus market value of equity divided by book value of assets, the finding implies that the market investor values positively the firm's Green_R\&D and R\&D expenditure. For example, as the result in Column (1) indicates, in a hypothetical world where a firm's R\&D takes its mean value, the effect of an increase in one inter-quartile range of Green_R\&D(=0.59) is around $2.0 \%$. This $2 \%$ is equivalent to $1.54 \%$ of (average) Tobin's Q values. However, this dynamic is attenuated as a firm raises its R\&D increases more than its mean value. For example, as a firm increases one inter-quartile value of $R \& D$ from its mean value, the marginal effect of increase in one inter-quartile of Green_R\&D on Tobin’s Q drops from 2.0\% to $1.7 \%$. 
Similarly, in a hypothetical world where a firm's Green_R\&D takes its mean value, the effect of an increase in a one inter-quartile range of $\mathrm{R} \& \mathrm{D}(=5.348)$ is $2.1 \%$. However, as a firm increases one inter-quartile value of Green_R\&D from its mean value as well, the marginal effect of an increase in one inter-quartile of $R \& D$ on firm performance drops from $2.1 \%$ to $1.8 \%$.

Table 4

Effects of Green_R\&D, R\&D and Carbon Emissions on Tobin’s Q

\begin{tabular}{|c|c|c|c|c|c|c|}
\hline & $\begin{array}{l}\text { Tobin's q } \\
\text { (1) }\end{array}$ & $\begin{array}{l}\text { Tobin’s q } \\
\text { (2) }\end{array}$ & $\begin{array}{l}\text { Tobin’s q } \\
\text { (3) }\end{array}$ & $\begin{array}{l}\text { Tobin's q } \\
\text { (4) }\end{array}$ & $\begin{array}{l}\text { Tobin’s q } \\
\text { (5) }\end{array}$ & $\begin{array}{l}\text { Tobin's q } \\
\text { (6) }\end{array}$ \\
\hline \multirow[t]{2}{*}{ Green_R\&D_C } & $0.035^{* *}$ & & $0.033^{*}$ & $0.095 * * *$ & $0.030 *$ & $0.087 * * *$ \\
\hline & [0.045] & & {$[0.056]$} & {$[0.000]$} & [0.085] & {$[0.000]$} \\
\hline \multirow[t]{2}{*}{ R\&D_C } & $0.004 * * *$ & & $0.004 * * *$ & $0.011 * * *$ & $0.005^{* * *}$ & $0.012 * * *$ \\
\hline & {$[0.000]$} & & {$[0.000]$} & {$[0.000]$} & {$[0.001]$} & {$[0.000]$} \\
\hline \multirow[t]{2}{*}{ Green_R\&DXR\&D_C } & $-0.001^{* * *}$ & & $-0.001 * *$ & $-0.001^{* * *}$ & $-0.001 * * *$ & $-0.001 * * *$ \\
\hline & {$[0.001]$} & & {$[0.001]$} & {$[0.000]$} & {$[0.001]$} & {$[0.000]$} \\
\hline \multirow[t]{2}{*}{$\mathrm{CO} 2$} & & $-0.014 * * *$ & $-0.013^{* * *}$ & $-0.009 * * *$ & $-0.008 * *$ & $-0.010 * *$ \\
\hline & & {$[0.000]$} & {$[0.000]$} & [0.004] & [0.041] & [0.011] \\
\hline \multirow[t]{2}{*}{ Energy_Intensive } & & & & & $-0.152 * * *$ & $0.106^{* *}$ \\
\hline & & & & & {$[0.008]$} & [0.047] \\
\hline \multirow{2}{*}{\multicolumn{2}{|c|}{ Green_RDXRDXEnergy_Intensive }} & & & & $0.001 *$ & $0.001^{*}$ \\
\hline & & & & & [0.087] & [0.057] \\
\hline \multirow[t]{2}{*}{ Capital intensity } & & & & $-0.029 * * *$ & & $-0.029 * * *$ \\
\hline & & & & {$[0.000]$} & & {$[0.000]$} \\
\hline \multirow[t]{2}{*}{ Firm size } & & & & $0.092 * * *$ & & $0.082 * * *$ \\
\hline & & & & {$[0.000]$} & & {$[0.000]$} \\
\hline \multirow[t]{2}{*}{ Leverage } & & & & $-0.006^{* * *}$ & & $-0.007 * * *$ \\
\hline & & & & [0.000] & & [0.000] \\
\hline \multirow{3}{*}{$\begin{array}{l}\text { Year-Industry effect } \\
\text { _cons }\end{array}$} & Yes & Yes & Yes & Yes & Yes & Yes \\
\hline & $1.528 * * *$ & $1.340 * * *$ & $1.565^{* * *}$ & $0.742 * * *$ & $1.730 * * *$ & $0.598 * * *$ \\
\hline & [0.000] & {$[0.000]$} & {$[0.000]$} & [0.000] & [0.000] & [0.001] \\
\hline $\mathrm{N}$ & 903 & 2773 & 896 & 896 & 896 & 896 \\
\hline $\mathrm{R} 2$ & 0.033 & 0.01 & 0.04 & 0.112 & 0.047 & 0.09 \\
\hline R2_a & 0.029 & 0.01 & 0.035 & 0.104 & 0.04 & 0.081 \\
\hline
\end{tabular}

\section{Conclusion and Implications}


The RBV and NRBV allow analysis of the effect of R\&D, in particular the effect of green R\&D investment, on environmental and financial performance. As discussed previously, a firm's environmental performance and R\&D possess characteristics of both the RBV and the NRBV, making them key resources that will allow a firm to achieve superior environmental and financial performance. Given the importance of these resources to a firm's performance, recent studies claim that $R \& D$ must be included to accurately measure how corporate social responsibility affects a firm's economic performance (McWilliams and Siegel, 2000; Padgett and Galan, 2010). This investigation adopted both R\&D and green R\&D for eco-innovation. Since existing studies have not provided a clear distinction between $R \& D$ and green $R \& D$, measuring the relationship between $R \& D$ and eco-innovation is difficult. That is, how general $R \& D$ made a signification contribution to environmental and financial performance is very unclear. Thus, with the aim of giving better explanations for the link between green $R \& D$ and carbon emissions, this research focuses on green $R \& D$, which specifies R\&D activities for eco-innovation in product, process, and operational efficiencies.

The results confirm that a firm's green R\&D investment decreases carbon emissions and increases firm value, measured by Tobin's Q. Therefore, findings support the presence of a negative relationship between green $R \& D$ investment and carbon emissions. At the same time, green R\&D is positively related to financial performance at the firm level. Notably, "firms accumulate valuable resources and capabilities that lead to superior firm performance" (Bansal, 2005, p. 197). This study confirms that green R\&D contributes simultaneously to superior environmental performance (carbon emission reductions) and financial performance (Tobin’s Q). This finding explicitly supports the need for unique organizational resources and capabilities to buttress a proactive environmental strategy. These resources and capabilities in turn make contributions for competitive advantage.

This paper is subject to limitations. First, the study's focus is on green R\&D investment that a firm makes for eco-innovation, which aims at reducing environmental impacts in product, process, and operational efficiencies. This focus limits the study's sample to manufacturing industries in which green $R \& D$ is a significant proportion of total $R \& D$. Therefore, the study’s findings are not readily applicable to non-manufacturing industries that have little green R\&D activity, and some caution should be exercised in generalizing the findings across different industries and firms. Second, the study relies on Japanese manufacturing firms because the Japanese sample during the period of 2001-2010 provides different insights on eco-innovation and green R\&D. Since green $R \& D$ is likely to be 
affected by national environmental regulations and policies as well as market pressures, researchers should be cautious when attempting a comparison with other countries.

Notwithstanding these caveats, this paper contributes to the research on $R \& D$ investment and a firm's environmental and financial performance by considering green $R \& D$ investment and carbon emissions. This examination constitutes another important empirical study to support the debate on the link between R\&D investment and firm performance. Future research could be directed at broadening the model to further consider important variables such as the global economic crisis and national environmental regulations. In addition, this investigation uses firm-level data to investigate firms' decisions on allocation of resources for eco-innovation. Since industry-level data are very limited with respect to a firm's strategy in resource allocation and capability development, the study's firm-level data add value to examination using the RBV and NRBV in Japanese manufacturing firms. Finally, Japanese innovation and manufacturing development still plays important roles in new product development, production, and operations in many developed and developing countries, and investigation of Japanese eco-innovation and green R\&D management practices has important managerial implications -in particular, that a proactive environmental strategy of employing valuable resources and capabilities to minimize environmental impacts and to increase operational efficiencies would lead to a competitive advantage.

\section{Acknowledgements}

We would like to thank conference participants in 2012 EURAM, 2013 EMAN for the useful remarks and suggestions. We also benefited from the constructive comments from Stephan Vachon. All remaining errors are ours. 


\section{References}

Ambec S, Lanoie, P. 2008. Does it pay to be green? A systematic overview. Academy of Management Perspective 22(4), 45-62.

Aragón-Correa A, Hurtado-Torres N, Sharma S, García-Morales J. 2008. Environmental strategy and performance in small firms: a resource-based perspective. Journal of Environmental Management 86(1), 88-103.

Arora S, Cason T. 1996. Why do firms volunteer to exceed environmental regulations? Understanding participation in EPA’s 33/50 program. Land Economics 72(4), 413-432.

Bansal P. 2005. Evolving sustainably: a longitudinal study of corporate sustainable development. Strategic Management Journal 26, 197-218.

Brammer S, Millington A. 2008. Does it pay to be different? An analysis of the relationship between corporate social and financial performance. Strategic Management Journal 29, 13251343.

Cheng C, Yang C, Sheu C. 2014. The link between eco-innovation and business performance: a Taiwanese industry context. Journal of Cleaner Production 64, 81-90.

Cole M, Elliott R, Shimamoto K. 2005. Industrial characteristics, environmental regulations and air pollution: An analysis of the UK manufacturing sector. Journal of Environmental Economics and Management 50, 121-143.

Dangelico R, Pujari D. 2010. Mainstreaming green product innovation: why and how companies integrate environmental sustainability. Journal of Business Ethics 95(3), 471-486.

Demsetz, H. and K. Lehn, 1985. The Structure of Corporate Ownership: Causes and Consequences, Journal of Political Economy 93, 1155-1177.DeSarbo W, Benedetto C, Song M, Sinha I. 2005. Revisiting the Miles and Snow strategic framework: uncovering interrelationships between strategic types, capabilities, environmental uncertainty, and firm performance. Strategic Management Journal 26(1), 47-74.

Elsayed K, Paton D. 2005. The impact of environmental performance on firm performance: static and dynamic panel data evidence. Structural Change and Economic Dynamics 16, 395412.

Etzion D. 2007. Research on Organizations and the Natural Environment, 1992-Present: A review. Journal of Management 33(4), 637-664.

Ford J, Steen J, Verreynne M. 2014. How environmental regulations affect innovation in the Australian oil and gas industry: going beyond the Porter Hypothesis. Journal of Cleaner Production http://dx.doi.org/10.1016/j.clepro.2013.12.062. 
Ghisetti C, Rennings K. 2014. Environmental innovations and profitability: how does it pay to be green? An empirical analysis on German innovation survey. Journal of Cleaner Production, http://dx.doi.org/10.1016/j.jclepro.2014.03.097.

Gonzalez-Benito J, Gonzalez-Benito Ó. 2005. Environmental proactivity and business performance: an empirical analysis. Omega 33(1), 1-15.

Griffin J, Mahon J. 1997. The corporate social performance and corporate financial performance debate: Twenty-five years of incomparable research. Business and Society 36, 5-31.

Gutowski T, Murphy C, Allen D, Bauer D, Bras B, Piwonka T, Sheng P, Sutherland J, Thurston D, Wolff E. 2005. Environmentally benign manufacturing: observations from Japan, Europe and the United States. Journal of Cleaner Production 13(1), 1-17.

Hayashi, H., 1983, Tobin's marginal q and average q: A neoclassical interpretation, Econometrica 50:213-224.

Hart SL. 1995. A natural-resource based view of the firm. Academy of Management Review 20(4), 98-113.

Hart SL, Ahuja G. 1996. Does it pay to be green? An empirical examination of the relationship between emission reduction and firm performance. Business Strategy and the Environment 5(1), 30-37.

Hart SL. 2005. Innovation, creative destruction and sustainability. Research Technology Management 48(5), 21-27.

Hart SL, Dowell G. 2011. A natural-resource-based view of the firm: fifteen years after. Journal of Management 37(5), 1464-1479.

Khanna M, Anton W. 2002. Corporate environmental management: Regulatory and marketbased incentives. Land Economics 48(2), 289-299.

King A, Lenox M. 2002. Exploring the locus of profitable pollution reduction. Management Science 48(2), 289-299.

Klassen R, McLaughlin C. 1996. The impact of environmental management on firm performance. Management Science 42(8), 1199-1214.

Klassen R, Whybark D. 1999. The impact of environmental technologies on manufacturing performance. Academy of Management Journal 42(6), 599-615.

Kemp R, Pearson P. 2008. Final Report MEI Project about Measuring Eco-Innovation: Deliverable 15 of MEI Project (D15), available at http://www.oecd.org/greengrowth/ consumption-innovation/43960830.pdf. (accessed 16 May 2014). 
Lee K-H. 2009. Why and how to adopt green management into business organizations?: The case study of Korean SMEs in manufacturing industry. Management Decision 47(7), 11011121.

Lee K-H, Ball R. 2003. Achieving sustainable corporate competitiveness. Greener Management International 44(Winter), 89-104.

Lee K-H, Kim J. 2011. Integrating suppliers into green product innovation development: An empirical case study in semiconductor industry. Business Strategy and the Environment 20(8), 527-538.

Lee K-H, Min B. 2014. Globalization and carbon constrained global economy: A fad or a trend? Journal of Asia-Pacific Business 15(2), 105-121.

Melnyk SA, Sroufe RP, Calantone R. 2003. Assessing the impact of environmental management systems on corporate and environmental performance. Journal of Operations Management 21, 329-351.

Menguc B, Ozanne L. 2005. Challenges of the green imperative: a natural resource based approach to the environmental orientation-business performance relationship. Journal of Business Research 58, 430-438.

Ministry of Economy, Trade and Industry, Environmental Report Plaza, 2002-2012.

Nikkei Economic Electronic Databank System http://www.nikkeieu.com/needs/pdf/needs_data/corporate_financial.pdf. 2012.

Padgett R, Galan J. 2010. The effect of R\&D intensity on corporate social responsibility. Journal of Business Ethics 93, 407-418.

Palmer K, Oates E, Portney R. 2005. Tightening environmental standards: the benefit-cost or the no-cost paradigm? Journal of Economic Perspectives 9(4), 119-132.

Porter M, van der Linde C. 1995. Towards a new conception of environment-competitiveness relationship. Journal of Economic Perspectives 9(4), 119-132.

Porter M, Reinhardt F. 2007. A strategic approach to climate. Harvard Business Review 85(10), 22-26.

Pujari D, Peattie K, Wright G. 2004. Organizational antecedents of environmental responsiveness in industrial new product development. Industrial Marketing Management 33, 381-391.

Roome N. 1994. Business strategy, R\&D management and environmental imperatives. R \& D Management 24(1), 65-83.

Russo M, Fouts P. 1997. A resource-based perspective on corporate environmental performance and profitability. Academy of Management Journal 40, 534-559. 
Sambasivan M, Bah S, Jo-Ann H. 2013. Making the case for operating “Green”: impact of environmental proactivity on multiple performance outcomes of Malaysian firms. Journal of Cleaner Production 42, 69-82.

Sharma S, Aragón-Correa A, Rueda-Manzanares A. 2007. The contingent influence of organizational capabilities on proactive environmental strategy in the service sector: An analysis of North American and European Ski Resorts. Canadian Journal of Administrative Sciences 24(4), 268-283.

Triguero A, Moreno-Mondejar L, Davia M. 2013. Drivers of different types of ecoinnovation in European SMEs. Ecological Economics 92, 25-33.

Walley N, Whitehead B. 1994. It’s not easy being green. Harvard Business Review 72(3), 27. 